\title{
Factors influencing farmers' behavior in rice seed selling in the market: a case study in the Tarai region of $\mathrm{Nepal}^{\mathrm{d}}$
}

\author{
Narayan P Khanal ${ }^{*}$ and Keshav L Maharjan
}

* Correspondence:
narayankhanal36@gmail.com
Graduate School for International
Development and Cooperation
(IDEC), Hiroshima University, 1-5-1
Kagamiyama, Hiroshima 739-8529,
Japan

* Correspondence: narayankhana136@gmail.com Development and Cooperation (IDEC), Hiroshima University, 1-5-1 Japan

\begin{abstract}
The importance of rice in food security and livelihoods of Nepalese people is well recognized but the seed supply system of this crop in the rural areas is poorly developed. To increase farmers' access to a wide range of rice varietal choices in a cost effective way, some farmers, organized in groups or cooperatives, have started producing and marketing rice seed through development projects in recent years. But very limited information has been published about the performance of the farmers in rice seed marketing. In this study, we analyze the impact of households' socio-economic variables on market participation and volume of rice seed sold, using a Heckman selection model. Data for the study were collected from three Tarai districts (Siraha, Kailali and Chitwan) in Nepal with a sample size of 180, that is, 60 households from each district. Result shows that $65 \%$ of households sell $64 \%$ of rice seed produced. Households with agricultural training, share contribution to their organization and higher livestock numbers are more likely to participate in the market. Similarly, households with older household heads, higher operational land, and access to an irrigation facility sell a higher amount of rice seed in the market. Seed price has a positive influence both on market participation and seed volume sold.

Keywords: Farmers' behavior; Rice seed selling; Market participation; Heckman selection; Nepal
\end{abstract}

\section{Background}

Rice is the most important food crop in Asia as it contributes $60 \%$ of households' calorie consumption, and about $90 \%$ of the world's rice output is produced and consumed in the continent (FAOSTAT 2012). Rice provides 20\% of agricultural gross domestic product, $40 \%$ of calorie and $25 \%$ of protein requirements in the Nepalese diet from cereals (MoAC 2010a). In spite of this, rice yield in Nepal is $2.9 \mathrm{t} \mathrm{ha}^{-1}$, which is lower than that of neighboring countries (India- $3.5 \mathrm{t} \mathrm{ha}^{-1}$, Bangladesh- $4.4 \mathrm{t} \mathrm{ha}^{-1}$, China$\left.6.6 \mathrm{t} \mathrm{ha}^{-1}\right)$, and the world average $\left(4.2 \mathrm{t} \mathrm{ha}^{-1}\right)$ (FAOSTAT 2012). In addition, there is high $(50 \%)$ disparity between potential and national average rice yield in this country. One of the reasons for this is poor access to quality seeds by farmers, which is evident from the poor seed replacement rate $(S R R)^{\mathrm{a}}$. The recommended SRR for selfpollinated crops including rice is $25 \%$ but its SRR was only $8.7 \%$ in Nepal in 2010 . This means only $8.7 \%$ of the total rice area received quality seed in that year, and the rice

\section{Springer}


seed required for the remaining area was supplied from informal sources such as rice grain reserved from previous season's harvest or local exchange of rice seed with neighbours (SQCC 2011). Also, the share of the government corporation also known as 'National Seed Company' in rice seed supply in 2010 was only $17 \%$, and rest of the seed was supplied through development projects, farmers' groups, cooperatives, and agrovets-small traders supplying agricultural inputs (SQCC 2011; Pokhrel 2012). The involvement of private companies in rice seed supply is quite low $(<5 \%)$, which might be due to low profit margin and high fluctuation of rice seed demand in the market (Almekinders et al. 1994; Lal et al. 2009; SQCC 2011). In Nepal, rice is grown from Tarai (from $70 \mathrm{~m}$ to $650 \mathrm{~m}$ above mean sea level-amsl) to hills (up to $3,050 \mathrm{~m}$ amsl-the highest rice growing altitude in the world), with the dominance of small farmers (average land holding 0.8 ha per household with $50 \%$ of households have $<0.5$ ha) (CBS, 2003). Also, variation exists across the production plots of the same household in terms of irrigation facility and soil characteristics (MoAC 2010a). To address opportunities and constraints associated with the above-mentioned variations together with climate and market factors, farmers tend to diversify their rice varietal portfolio using both modern (those developed from research organisations) varieties and local landraces (Gauchan et al. 2005; Khanal \& Maharjan 2013). This demands a mechanism that supplies a wide range of rice varieties to farmers in a cost effective way.

From the 1990s, government and Non-Government Organizations (NGOs) started facilitating farmers' groups and cooperatives (also called as community-based seed producer organizations-CBSPOs) in rice seed production and marketing through action research, and development projects (Lal et al. 2009; Witcombe et al. 2010). Government statistics show that 146 registered CBSPOs with 3,500 members (households) were involved in rice seed production in 2009. The majority of these registered CBSPOs (80\%) are from the Tarai region, the food basket of Nepal, contributing $70 \%$ of the total rice produced in the country (MoAC 2010b). The CBSPOs have also been promoted in other countries of Asia and Africa to contribute in the local seed supply of various food crops including rice (David 2004; Bishaw \& van Gastel 2008; Srinivas et al. 2010). It is believed that CBSPOs could produce and market rice seed in a cost effective way because these activities are handled by farmers at local levels. Also, farmers are in a better position than other actors such as government agencies and private companies to select appropriate rice varieties suitable for local niches due to their experience in rice farming and informal networks (Almekinders et al. 1994).

In spite of the great potential of CBSPOs in supplying seeds of different rice varieties at local level, it is not clear how small farmers could increase their participation in marketing (Almekinders et al. 1994; Setimela et al. 2004; Pokhrel 2012). Very few studies have been published on this issue (David 2004; FAO 2010; Srinivas et al. 2010; Witcombe et al. 2010), and the focus of these studies is on the ability of CBSPOs to cover marketing (processing, storage and distribution) costs and provide additional benefits to their members (farmers) using estimated seed production data. These studies might have limited policy implications as the estimated production data would be less likely to represent the actual volume of seed sold by households in the market. This is because in developing countries the cereal seed industry is in an early development stage, and farmers tend to sell part of their agricultural produce in the market and the remaining output is consumed at home, and/or exchanged with neighbours as seed or 
grain (Amekinders \& Louwaars 1999). Since rice seed production is carried out at household level and marketing through their organization, household characteristics could play a vital role in farmers' performance in rice seed marketing. This article intends to measure the impact of households' socio-economic factors on rice seed marketing.

\section{Literature review}

Microeconomic theory explains the farmers' behaviors in selling seed in the market. According to theory, producers' and consumers' behaviors in the market varieties with market signals. It means the volumes of commodity supplied in the market chain is guided by price, and there is no barrier to entry and exist of enterprises in the market chain. However, it is difficult to explain farmers' behaviors in selling agricultural produce in subsistence farming considering only price signal, whereby farmers do not sell a significant portion of seeds produced (Almekinders \& Louwaars 1999; Omti et al. 2009). Previous studies indicate that farmers' participation in marketing is constrained by productivity (Janvry et al. 1991; Fafchamps 1992), poverty, information, and physical constraints including road and storage facilities. Heltberg and Tarp (2002) found that farm size, animal manure, age of household head (HHH), ownership of transportation means and strategies to adapt to climate risk to be positively associated with market participation. All these variables are related to productivity enhancement. Similarly, Benfica et al. (2006) found a significant positive impact of education of household head, access to credit and households' off-farm income on market participation. Access to storage facility is another challenge for farmers in rice seed marketing (Barrett 2006). Despite the availability of some literature about the impact of households' socioeconomic characteristics, local level and crop specific studies are needed to make appropriate policy recommendations.

\section{Methods}

\section{Study site and sampling technique}

A field survey was carried out in three districts (Sirha, Chitwan and Kailali) of the region of Taria in Nepal, representing Eastern, Central and Far-western development regions, respectively. A multi-stage random sampling method was used to select the sample households. In each district, first, CBSPOs having at least two years experience in rice seed production and marketing were selected in consultation with District Agriculture Development Offices (DADOs). Then, in the second step, 15 members from each of the selected CBSPOs were randomly selected, making the total sample size of 180 for the survey. After the completion of the household survey, meetings were held with the selected CBSPOs to discuss issues raised during household survey. The survey was implemented in October and November 2011.

\section{Empirical model}

A Heckman selection model (Heckman 1979) was used for data analysis. This model is used where sample selection arises as a result of partial observation of the outcome variable. In the presence of sample selection, the observed outcome does not represent a random sample of its population. In this case, ordinary least square (OLS) regression 
could give biased results as it nullifies the censored observations. The Heckman selection model has been developed to address this problem. This model consists of two equations. The first equation is called the selection equation which is similar to a probit model, and it measures the impacts of socio-economic variables on the probability of households' selling rice seed in the market. The second equation, also calledoutcome equation, is similar to an OLS model and measures the impact of socio-economic variables on volume of seed sold in the market. These two equations are modeled by a two-step procedure or a one-step procedure. Though the two-step procedure has been frequently used in the literature, the one-stage procedure (simultaneously modeling of two equations using the maximum likelihood method) would be more efficient than the two-step procedure (Nawata \& Nagase 1996; Nawata 2004). Nawata (2004) argued that the one-step procedure is more appropriate than the two-step procedure if sample size is small. Considering these issues, we followed the one-step procedure in the study. Another consideration in the Heckman selection model is the use of an identifier variable which is used in selection equation and not in the outcome equation. We used rice seed price for this purpose. The outcome and selection equations are presented in equations 1 and 2, respectively.

$$
\begin{aligned}
& y_{i}=x_{i} \beta+\mu_{i} \\
& z_{i}^{*}=w_{i} \alpha+\epsilon_{i}
\end{aligned}
$$

where $y_{i}$ is volume of seed sold in the market, $Z_{i}^{\prime \prime}$ is a latent variable, $x_{i}$ and $w_{i}$ are the vectors of explanatory variables, $\beta$ is the vector of coefficients, and $\mu_{\mathrm{i}}$ and $\epsilon_{i}$ are the error terms.

The operational models of the outcome and selection equations are given in equations 3 and 4, respectively.

$$
\begin{aligned}
& \text { In seed sold }=\beta_{0}+\beta_{1} \text { age of } \mathrm{HHH}+\beta_{2} \text { education of } \mathrm{HHH}+\beta_{3} \text { family labor }+ \\
& \beta_{4} \text { cultivated land }+\beta_{5} \text { ln off-farm income }+\beta_{6} \text { irrigation }+\beta_{7} \text { livestock }+ \\
& \beta_{8} \text { training }+\beta_{9} \text { share }+\beta_{10} \text { roof type }+\mu_{\mathrm{i}} \\
& \text { Market participation }=\alpha_{0}+\alpha_{1} \text { age of } \mathrm{HHH}+\alpha_{2} \text { education of } \mathrm{HHH}+\alpha_{3} \text { family labor } \\
& +\alpha_{4} \text { cultivated land }+\alpha_{5} \text { ln of-farm income }+\alpha_{6} \text { irrigation }+\alpha_{7} \text { livestock }+\alpha_{8} \text { training } \\
& +\alpha_{9} \text { share }+\alpha_{10} \text { roof type }+\alpha_{11} \text { seed price }+\epsilon_{i}
\end{aligned}
$$

where $\ln$ is $\log$. Seed sold is the dependent variable used in the outcome equation which indicates the quantity of rice seed sold by farmers in the market.

It is possible that farmers' sell seed not only to CBSPOs but also to other actors such as local farmers, agrovets, and development projects. However, CBSPOs and DADOs in group discussions argued that farmers in the study area rarely sell seed directly to other actors. Rather they sell seed to the CBSPOs where they have taken membership, and the CBSPOs after processing (packaging, quality checking and leveling) sell seeds to the aforementioned actors. So, we consider CBSPOs are the markets for farmers. Similarly, market participation is the dependent variable in the selection equation which shows whether farmers sell seed to CBSPOs or not (i.e. a dummy variable which takes the value 0 or 1$)$. 
A total of 11 socio-economic variables were chosen as explanatory variables considering economic theory, findings from previous literature and experience of farmers as the combination of these strategies would help to draw the relevant variables for the study (Table 1). These variables include demographic (age and education of $\mathrm{HHH}$, and family labor), economic (cultivated land, irrigation facility, off-farm income, livestock and roof type), and institutional (training, and having a share in an CBSPO). The justification for the selection of these variables is given below.

The impact of age and education of $\mathrm{HHH}$ was hypothesized to be positive because age represents experience and education indicates analytical capability, both of which might have a positive impact on households' market participation and volume of seed sold (Heltberg and Tarp 2002). Similarly, rice seed production is carried out in rural areas where the majority of the work is done by the family members. Also, rice farming is seasonal in nature when most of labourers are busy in their own households' activities. Even those wanting to hire labourers might not get them on time and could not carry out field activities properly, which might influence the quantity and quality of rice seed. So, it was hypothesized that family labour (Labour force unit-LFU ${ }^{\mathrm{b}}$ ) would have a positive impact on both market participation and seed sale volume.

Amount of cultivated land, irrigation facility (proportion of the total amount cultivated land with irrigation facility) and organic manure have a positive linkage with crop yield (Azam et al. 2012), so these variables were assumed to have a positive impact on the marketing indicators. We used livestock (Livestock Standard Unit-LSU') as a proxy variable to represent the amount of animal manure applied in rice fields. Similarly, those having higher off-farm income might be less affected by cash/food shortage, especially the period between rice crop harvest and its seed sale, and would be more motivated towards marketing. Moreover, the CBSPOs might be poor in physical structure (e.g., storage house, grading machine) in the early phase of the cereal seed industry development. This implies that seed growers might have to store seed at their personal

Table 1 Description of variables and expected sign

\begin{tabular}{|c|c|c|c|}
\hline Variables & Definition & Mean \pm SD & Expected sign \\
\hline Seed sold & Amount of rice seed sold by farmers (kg) & $1,356.7 \pm 144.3$ & \\
\hline Seed selling & $1=$ if they sell the seed, 0 for otherwise & $65.8 \pm 0.47$ & \\
\hline Age $\mathrm{HHH}$ & Age of $\mathrm{HHH}$ in years & $46.83 \pm 11.43$ & + \\
\hline Education $\mathrm{HHH}$ & Formal schooling years of $\mathrm{HHH}$ & $7.96 \pm 4.02$ & + \\
\hline Family labor & Labor force unit (LFU) ${ }^{2}$ at household & $3.44 \pm 1.44$ & + \\
\hline Cultivated land & Total operational land for rice seed production (ha) & $0.95 \pm 0.36$ & + \\
\hline Off-farm income & $\begin{array}{l}\text { Annual cash income of household members from } \\
\text { off-farm sources (NRs) }\end{array}$ & $42,998 \pm 38,234$ & + \\
\hline Irrigation & $\%$ operational land area under irrigation facility & $54.5 \pm 26.8$ & + \\
\hline Livestock & Livestock standard unit (LSU) ${ }^{1}$ & $3.86 \pm 5.77$ & + \\
\hline Training & $\begin{array}{l}1=\text { if household received seed management training } \\
0=\text { otherwise }\end{array}$ & $0.783 \pm 0.413$ & + \\
\hline Share & $1=$ If farmers put share in CBSPOs, $0=$ otherwise & $0.644 \pm 0.480$ & + \\
\hline Roof type & $1=$ if households have concrete roof and $\mathrm{o}=$ otherwise & $0.338 \pm 0.645$ & + \\
\hline Seed price & Price of rice seed (NRs per kg) & $18.02 \pm 2.81$ & + \\
\hline
\end{tabular}

1 US\$ = NRs. 82.96 (Nepal Rastra Bank, 2011.11.30)

Source: Field survey, 2011. 
houses for a few months after the rice harvest until CBSPOs make arrangements to store it in their warehouses. Those having concrete-roofed houses would be more likely to be motivated towards marketing than their counterparts as they could store the seed maintaining quality.

Training and household's share holdings (cash deposited at CBSPOs by farmers) are the two institutional variables considered in the study. It was assumed that those receiving training in any aspect of seed management (production, quality control and marketing) might be better off both in the market participation and seed selling volume as training tends to enhance households motivation towards marketing. Similarly, those who deposited cash at CBSPOs as share were assumed to have better performance in marketing. It is because profit generated from the marketing of seed could be distributed to households based on the proportion of share amount they deposit at CBSPOs. The detail of dependent and explanatory variables used in the study is presented in Table 1.

Before running the Heckman selection model, data were validated for multicollinearity and heteroskedasticity. The Variance Inflation Factor (VIF) method was used to detect multicollinearity because this method is preferred over the correlation coefficient method (Pindyck \& Rubinfield 1981). We did not find a problem of multicollinearity in the explanatory variables used in the model as the values are less than 10 . The test for homogeneity of variance was conducted using the Breusch-Pagan/Cook-Weisberg test for heteroskedasticity, and the hypothesis of constant variances of the residuals was not rejected $(p>0.25)$ in both equations. Moreover, endogeneity issue was checked across the price variables in both the equations through Hausman test and did not find problem.

\section{Results}

\section{Summary of the selected variables}

The study shows that $65.8 \%$ of farmers sold rice seed in the market on average $1,356.7 \mathrm{~kg}$ household ${ }^{-1}$ and this volume is $64 \%$ of the total rice seed produced by households (Table 1 ).

The average amount of cultivated land for rice seed production per household was 0.95 ha, and this area represents $85 \%$ of the total amount of cultivated land 1.16 ha. Similarly, households make their livelihoods from various on-farm (cereal crop, vegetable, livestock, etc.), and off-farm (labor work, salaried job, small business and remittance) sources; however, the share of the latter sources to the annual households' average cash income is $69 \%$. The average age of $\mathrm{HHH}$ was 46.83 years but it varied from 17.0 to 75.0 years. The average LSU was 3.86 , and major animals raised by farmers include cows, buffaloes, goat and poultry. The majority of $\mathrm{HHH}$ in the study area received agricultural training (78.3\%) from government organizations and NGOs. About one third of the households (33.8\%) had concrete roofed houses. About twothird of the household (64.4\%) adopted the practice of depositing shares in their organizations. The average price of seed was NRs $18.02 \mathrm{~kg}^{-1}$ but it varied from NRs $17 \mathrm{~kg}^{-1}$ to NRs $24 \mathrm{~kg}^{-1}$.

\section{Output from Heckman selection model}

Table 2 presents the result from the Heckman selection model and shows that the variables chosen for the study fit this model well which is shown by the significant log 
Table 2 The impact of explanatory variables on outcome and selection equations

\begin{tabular}{lccccc}
\hline Variables & \multicolumn{2}{c}{ Outcome equation } & & \multicolumn{2}{c}{ Selection equation } \\
\cline { 2 - 3 } & Coefficient & Marginal impact & & Coefficient & Marginal impact \\
\hline Age HHH & $0.020(0.034)^{* *}$ & $0.019(0.036)^{* *}$ & & $-0.002(0.772)$ & $-0.001(0.773)$ \\
Education HHH & $0.027(0.401)$ & $0.031(0.342)$ & & $0.021(0.496)$ & $0.006(0.493)$ \\
Family labour & $0.0213(0.254)$ & $0.031(0.402)$ & & $0.027(0.498)$ & $0.009(0.503)$ \\
Cultivated land & $0.07(0.008)^{*}$ & $0.06(0.048)^{* *}$ & & $0.005(0.220)$ & $0.0017(0.229)$ \\
Off-farm income & $0.4(0.301)$ & $0.2(0.231)$ & & $0.1(0.746)$ & $0.1(0.856)$ \\
Irrigation & $0.0765(0.072)^{*}$ & $0.042(0.072)^{*}$ & & $0.112(0.795)$ & $0.036(0.794)$ \\
Livestock & $0.004(0.342)$ & $0.002(0.221)$ & & $0.09(0.094)^{*}$ & $0.071(0.048)^{* *}$ \\
Training & $0.074(0.76)$ & $0.0212(0.78)$ & & $0.182(0.009)^{* * *}$ & $0.155(0.014)^{* *}$ \\
Share & $0.081(0.815)$ & $0.114(0.309)$ & & $0.220(0.037)^{* *}$ & $0.190(0.037)^{* *}$ \\
Roof type & $0.271(0.212)$ & $0.259(0.217)$ & & $0.033(0.896)$ & $0.010(0.13)$ \\
Seed price & - & $0.11(0.084)^{*}$ & & $0.08(0.062)^{*}$ & $0.071(0.045)^{* *}$ \\
Constant & $6.433(0.001)^{* * *}$ & & & $2.95(0.008)^{* * *}$ & \\
\hline
\end{tabular}

Wald Chi $(10)=17.66$, Log likelihood statistics $=253.335, p 0.004 ; \rho=0.690$, Likelihood ratio test for $\rho=0$ is 0.690 , $p=0.027, \Sigma($ Sigma $)=1.098 ; \lambda($ Lambda $)=0.757$; No of observation $=180$, censored observations $=63$, uncensored observations $=117$.

Note: ${ }^{* * *}$ and ${ }^{* * *}$ indicate significance at $10 \%, 5 \%$ and $1 \%$ levels, respectively; figures in the parentheses are probability values.

likelihood function $(\mathrm{p}=0.004)$. It means that the coefficients of the explanatory variables used in the model are significantly different from zero. Also, the log likelihood ratio test rejected the hypothesis of the absence of correlation between the error terms of outcome $\left(\varepsilon_{1}\right)$ and selection $\left(\varepsilon_{2}\right)$ equations $(\rho=0.690, \rho=0.027)$. This justifies the estimation of these two equations simultaneously using the Heckman selection model. Since the above equations were modeled using the maximum likelihood method, the coefficients of the explanatory variables do not represent their average impact on the dependent variable. So, we estimated the marginal impacts of the explanatory variables on the dependent variables, and these impact values are used to discuss the degree of influence of these variables on the dependent variables. The study shows that the impact of most of the explanatory variables is in line with their hypothesized direction. Also, the impact of some variables is different between the outcome and selection equations.

The age of HHH has a statistically significant positive impact on the volume of seed sold in the market. However, its impact on market participation is not significant. This finding is consistent with that of Omit et al. (2009).

There is a significant positive impact of cultivated land on seed sold volume in the market but its effect on market participation is not significant as in the case of the age of $\mathrm{HHH}$. One ha increase in cultivated land leads to an increase of the seed volume sold by $6 \%$. Irrigation also showed a significant positive impact on seed volume sold which would be increased by $4.2 \%$ with an increase in the irrigated land by $1 \%$. These findings are also consistent with those of Azam et al. (2012).

In contrast to the above findings livestock, training and households' share in CBSPOs showed a significant positive impact on the households' participation in the market instead of volume of seed sold. As shown in Table 2, one unit increase in LSU leads to increase the probability of households' selling seed in the market by $7.1 \%$. Similarly, there is a significant positive impact of training on market participation. Trained households' 
probability to sell rice seed in the market is $15.5 \%$ higher than the non-attendees. The better performance of trained households in market participation might be due to their superior skills on seed quality management and commercial orientation (Witcombe et al. 2010).

Households' share in CBSPOs also showed a significant positive impact on market participation. There is a $19 \%$ higher probability of selling rice seeds among households who have deposited shares in CBSPOs than their counterparts. The seed price shows a significant positive impact on households' decision to participate in the market. One

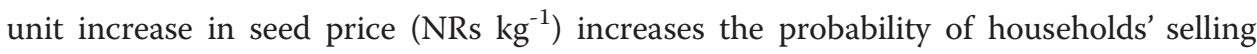
seed in the market by $7.1 \%$. Seed price has also an indirect impact on volume of seed sold in the market as shown from its marginal impact on seed sold volume (Table 2). One unit increase in seed price leads to an increase of seed sold volume by $11 \%$. The other variables such as family labour, education of $\mathrm{HHH}$ and roof type did not show a significant impact on seed marketing but it does not mean that they do not have any role in households' decision in selling seed in the market and volume of seed sold.

\section{Discussion}

In this study, we found that about two-thirds of the farmers have participated in the rice market in Nepal, and that they sell a similar proportion of the total produced rice as seeds, that is, one-third of the farmers did not sell seed in the market. Previous studies have also noted the issue of the poor participation of farmers in the market in developing countries. Almekinders et al. (1994) and Wiggins and Cromwell (1995) found poor market participation of farmers, especially those facilitated by development projects, in seed marketing. In some cases, these projects failed to collect seed back which was provided to farmers as loans (Almekinders et al. 1994; Wiggins and Cromwell 1995). One of the reasons for poor performance of farmers in seed marketing was due to the poor focus of these projects in delivering technical and marketing skills. Our study also recognized the importance of training on rice seed marketing. We found that farmers had taken training on crop husbandry, seed quality maintenance and marketing from projects implemented by NGOs and government agencies. Though $78.3 \%$ of the households attended agricultural training, only $65 \%$ of the market participants received marketing training from NGOs. It means some farmers got agricultural training from DADO (32\% of the sample households) but the content of these trainings was focused on technical aspects of seed production with little or no information about marketing and entrepreneurship aspects. This might be due to the influence of the policy document called 'District Seed Self-Sufficiency Program' which is focused on technical aspects of seed production (Lal et al. 2009; Witcombe et al. 2010).

Another motivating factor for farmers to participate in seed marketing is the system of share holdings in CBSPOs. Only 50\% of households reported that their CBSPOs have distributed profit generated from seed marketing to their members, but it has been mobilized as a loan to the members. About a quarter of the respondents (26\%) have taken loans from their CBSPOs for household activities. In addition to providing loans to their members, the revenue collected at the organization level has been mobilized for the development of a seed processing facility (storage building and grading machine). The practice of share holdings by households is considered important from q social 
perspective as well because it enhances households' ownership towards their organizations (CBSPOs). Moreover, households with higher share contributions to CBSPOs hold more voting rights (value) in the decision making process. This norm is similar to that of private companies and not to the general cooperative principle where one member one vote is applied regardless of the distribution of share amount among the members (Acharya 2008). However, $75 \%$ of the households included in this study are organized either in informal groups or cooperatives.

Similarly, this study recognized that three additional economic variables-livestock holding, cultivated land and irrigation facility-have a significant positive impact on the rice seed selling behavior of farmers. The significant impact of livestock on households' participation in the market might be due to its contribution to soil fertility and thereby on crop yield. There is a significant positive correlation between LSU and crop yield $(r=0.6, p=0.02)$. Livestock also contribute in households' cash income, but only $20 \%$ of farmers have received cash income from this sub-sector indicating the linkage of livestock on seed marketing is important mainly from its contribution towards increasing rice yield through improving soil fertility. Moreover, the impact of cultivated land and irrigation facility on seed selling volume is significantly different from zero. The correlation of these variables with rice yield is also positive, which implies that farmers with higher seed production area and better irrigation facility are more likely to sell higher quantities of seed in the market. However, strategies such as timely payment for seed or provision of credit and insurance system could address the small farmers' concerns, and those growing rice under rain-fed condition (Kugbei 2007).

\section{Conclusions}

Farmers' participation in rice seed production has been popular to increase access to diversified varieties in a cost effective way. However, to increase gains from seed production, farmers need to supply a maximum proportion of produced seed to the market. In this study, we analyzed the impact of households' socio-economic variables on the probability of households' rice selling seed in the market, and the volume of seed sold using a Heckman selection model. The result shows that $65 \%$ of farmers sell $64 \%$ of rice seed produced by their household. Out of the socio-economic variables, age of $\mathrm{HHH}$, cultivated land and irrigation facility have major impacts on seed volume sold, whereas the major impact of livestock, training and share holding is on farmers' market participation. Seed price directly impacts on farmers' market participation, and has also an indirect impact on seed volume sold. So, from this study we found four important variables: training, irrigation, soil fertility and share holdings that can have policy implications in motivating farmers in rice seed marketing in the study area.

\section{Endnotes}

${ }^{a} S R R$ is the proportion of rice area covered by quality seed in the country in a year.

${ }^{\mathrm{b}} \mathrm{LFU}$ is a measure for labour force, where people from 15-59 years old regardless of their sex were categorized as 1 person $=1 \mathrm{LFU}$, but in case of children (10-14 years old) and elderly people ( $>59$ years old) 1 person $=0.5 \mathrm{LFU}$.

${ }^{c} \mathrm{LSU}$ is the aggregate of different types of livestock kept at household in standard units calculated using the following equivalents; 1 adult buffalo $=1$ LSU, 1 immature 
buffalo $=0.5 \mathrm{LSU}, 1 \mathrm{cow}=0.8 \mathrm{LSU}, 1$ calf $=0.4 \mathrm{LSU}, 1 \mathrm{pig}=0.3 \mathrm{LSU}, 1$ sheep or goat $=$ $0.2 \mathrm{LSU}$ and 1 poultry or pigeon=0.1 LSU (CBS 2003).

${ }^{\mathrm{d}}$ Earlier version of the paper was presented in the 11th international conference on dry land development: global climate change and its impacts on food and energy security in the dry lands, organized by International Dryland Development Commission, 18-23 March, 2013 at Beijing.

\section{Abbreviations}

CBS: Central Bureau of Statistics; CBSPOs: Community-based seed producers' organizations; CIMMYT: International wheat and maize research center; DADOs: District Agriculture Development Office; DISSPRO: District seed selfsufficiency program; FAO: Food and Agriculture Organization; FAOSTAT: Food and Agriculture Organization Statistics; HHH: Household head; MoAC: Ministry of Agriculture and Cooperative, Kathmandu, Nepal; SQCC: Seed Quality Control Center; SRR: Seed replacement rate.

\section{Competing interests}

The authors declare that they have no competing interests.

\section{Authors' contributions}

NPK: involved in different steps: research design, data collection, analysis and preparation of draft involved in the preparation of this article. KLM was involved in research design and editing of the document. Both authors read and approved the final manuscript.

\section{Author's information}

Narayan P Khanal is an Assistant Professor at the Graduate School for International Development and Cooperation (IDEC), Hiroshima University, Hiroshima, Japan.

\section{Acknowledgements}

We are thankful to Global Environmental Leader program of Hiroshima University for providing grant for field study. Similarly, supports from Forum for Rural Welfare and Agricultural Reform for Development (FORWARD Nepal) in data collection process.

Received: 18 March 2013 Accepted: 11 November 2013

Published: 03 Dec 2013

\section{References}

Acharya BM (2008) Is cooperative really a democratic organization? Lessons learnt from the selected cooperative acts of the world: annual bulletin. Cooperative Development Board, Kathmandu, Nepal

Almekinders C, Louwaars N (1999) Farmers' seed production: new approaches and practices. Available via www.acss. ws/Upload/XML/Research/99.pdf. Accessed 12 April 2011

Almekinders C, Louwaars NP, Bruijin GH (1994) Local seed system and their importance for an improved seed supply in developing countries. J Euphytica 78:207-216

Azam MS, Ima KS, Gaiha R (2012) Agricultural supply response and small holder market participation: the case of Combodia. Available via http://www.rieb.kobe-u.ac.jp/academic/ra/dp/English/DP2012-09.pdf. Accessed 10 Jan 2013

Barrett CB, Marenya PP, Mcpeak JG, Minten B, Murithi FM, Oluoch-Kosura W, Place F, Randrianarisoa JC, Rasambainarivo J, Wangila J (2006) Welfare dynamics in rural Kenya and Madagascar. J Dev Stud 78(3):656-669

Benfica R, Tschirly D, Boughton D (2006) Interlinked transaction in cash cropping economies: the determinant of farmers' participation and performance in the Zambezi River Vally of Mozambique. Contributed paper presented at the 26th international association of agricultural economists conference, Gold Coast, Australia. August 12-18, 2006

Bishaw Z, Van Gastel AJG (2008) ICARDA's seed delivery approach in less favorable areas through village-based seed enterprises: conceptual and organizational issues. J New Seeds 9(1):68-88

CBS (2003) National sample census of agriculture Nepal, 2001/02: highlights. National Planning Commission Secretariat, Central Bureau of Statistics, Kathmandu, Nepal

David S (2004) Farmer seed enterprises: a sustainable approach to seed delivery? J Agric Hum Values 21:387-397

De Janvry A, Fafchamps M, Sadoulet E (1991) Peasant household behavior with missing market: some paradoxes explained. Econ J 101(409):1400-1417

FAO (2010) Promoting the growth and development of small seed enterprises for food security crops. Available via www.fao.org/docrep/013/i1839e/i1839e00.pdf. Accessed 10 March 2011

FAOSTAT (2012) Crop information 2011. Available via http://faostat.fao.org/site/567/DesktopDefault.aspx? PagelD=567\#ancor. Accessed 2 February 2013

Fafchamps M (1992) Cash crop production, food price volatility and rural market integration in the third world. Am J Agric Econ 74(1):90-99

Gauchan DM, Smale M, Chaudhary P (2005) Market-based incentive for conserving diversity on-farm: the case of rice landraces in central Tarai, Nepal. Genet Res Crop Evol 52:293-303

Heckman JJ (1979) Sample selection bias as a specification error. J Econometrica 47(1):53-161

Heltberg R, Tarp F (2002) Agricultural supply response and poverty in Mozambique. Food policy 27(1):103-124

Khanal NP, Maharjan KL (2013) Socio-economic determinants for the adoption of improved rice varieties in the tarai region of Nepal. J Int Dev Cooperation, Hiroshima University, Special Issue 19(4):17-27 
Kugbei S (2007) Seed economics: commercial consideration for enterprise management in developing countries: international center for agricultural research in the dry areas. Scientific Publishers, India

Lal KK, Thapa M, Guenat D (2009) Review of seed projects in Nepal. Swiss Agency for Development and Cooperation Kathmandu, Nepal

MoAC (2010a) Statistical Information on Nepalese Agriculture. Ministry of Agriculture and Cooperatives, Singha Durbar, Annual Report, Nepal

MoAC (2010b) Seed production groups and cooperatives in Nepal. Ministry of Agriculture and Cooperative, Nepal Nawata K (2004) Estimation of the female labor supply model by Heckman's two-step estimator and maximum likelihood estimator. Math Comput Simul 64:385-392

Nawata K, Nagase N (1996) Estimation of sample selection method. Econometric Rev 15:387-400

Omiti JM, Otieno DJ, Nyanamba TO, Mccullough E (2009) Factors influencing the intensity of market participation by smallholder farmers: a case study of rural and peri-urban areas of Kenya. Available via http://ageconsearch.umn. edu/bitstream/56958/2/0301Omiti\%20-\%20FINAL.pdf. Accessed 4 December 2012

Pindyck RS, Rubinfield D (1981) Econometric models and economic forecasts. McGraw Hill, New York, USA

Pokhrel S (2012) Role of DISSPRO and CBSP in current seed supply situation in Nepal. J Agric Environ 13:53-59

Setimela PS, Monyo E, Banjiger M (ed) (2004) Successful community based seed production strategies. CIMMYT, Mexico Srinivas T, Zewdie B, Javed R, Abdoul A, Rahaman A, Amegbeto K (2010) ICARDA's approach in seed delivery: technical performance and sustainability of village-based seed enterprises in Afghanistan. J New Seeds 11(2):138-163

SQCC (2011) Seed balance sheet 2011. Available via http://sqcc.gov.np/. Accessed 4 February 2012

Wiggins S, Cromwell E (1995) NGOs and seed provision to smallholders in developing countries. World Dev 23:413-422 Witcombe JR, Devkota KP, Joshi KD (2010) Linking community-based seed producers to markets for a sustainable seed supply system. J Exp Agric 46(4):425-437

\subsection{6/2193-7532-1-14}

Cite this article as: Khanal and Maharjan: Factors influencing farmers' behavior in rice seed selling in the market: a case study in the Tarai region of Nepal ${ }^{d}$. Agricultural and Food Economics 2013, 1:14

\section{Submit your manuscript to a SpringerOpen ${ }^{\odot}$ journal and benefit from:}

- Convenient online submission

- Rigorous peer review

- Immediate publication on acceptance

- Open access: articles freely available online

- High visibility within the field

Retaining the copyright to your article

Submit your next manuscript at $\boldsymbol{\sim}$ springeropen.com 